\title{
The Effect of Incorporating Ultra-Fine Spherical Particles on Rheology and Engineering Properties of Commercial Ultra-High-Performance Grout
}

\author{
Wei-Ting Lin ${ }^{1, *} \mathbb{D}$, Wen-Que Zhao ${ }^{1}$, Yi-Hua Chang ${ }^{1}$, Jiann-Shi Yang ${ }^{2}$ and An Cheng ${ }^{1}$ \\ 1 Department of Civil Engineering, National Ilan University, No. 1, Sec. 1, Shennong Rd., Yilan City 260, \\ Yilan County, Taiwan; zwenque@gmail.com (W.-Q.Z.); kitty3658123@gmail.com (Y.-H.C.); \\ ancheng@niu.edu.tw (A.C.) \\ 2 Triaxis Corporation, 19F, Jinlu Business Building, No. 311, Yuelu Rd., Changsha 410031, China; \\ alan.yang@triaxis.com.cn \\ * Correspondence: wtlin@niu.edu.tw; Tel.: +886-3931-7567
}

\section{check for} updates

Citation: Lin, W.-T.; Zhao, W.-Q.; Chang, Y.-H.; Yang, J.-S.; Cheng, A. The Effect of Incorporating Ultra-Fine Spherical Particles on Rheology and Engineering Properties of

Commercial Ultra-High-Performance Grout. Crystals 2021, 11, 1040. https://doi.org/10.3390/ cryst11091040

Academic Editor: Alexander M. Korsunsky

Received: 16 July 2021

Accepted: 27 August 2021

Published: 29 August 2021

Publisher's Note: MDPI stays neutral with regard to jurisdictional claims in published maps and institutional affiliations.

Copyright: (c) 2021 by the authors. Licensee MDPI, Basel, Switzerland. This article is an open access article distributed under the terms and conditions of the Creative Commons Attribution (CC BY) license (https:// creativecommons.org/licenses/by/ $4.0 /)$.

\begin{abstract}
In this study, ultra-fine spherical particles of silica fume and reactive ultra-fine fly ash were added to a mixture of commercial ultra-high-performance grout (UHPG) with the aim of enhancing the rheological properties, compressive strength, compactness, and permeability. This commercial UHPG study was conducted in collaboration with Triaxis Corporation (Changsha city, Hunan province, China). A water-to-binder ratio of 0.21 and a binder-to-fine aggregates ratio of 1.17 were used as fixed parameters, and the binders were a combination of type-II Portland cement, sulphoaluminate cement, silica fume, and reactive ultra-fine fly ash (RUFA). Polycarboxylate superplasticizer powder was used to control the rheology. The results revealed excellent compressive strength, volume stability, and resistance to chloride penetration. Mercury intrusion porosimetry and scanning electron microscopy tests revealed that the medium-sized RUFA particles with small silica fume particles completely filled the spaces between large cement particles to achieve optimal densification. This mixture also produced dense hydration and calcium-silicate-hydrates colloids, which filled the microstructures of the UHPG resulting in excellent engineering properties and durability. This commercially available UHPG mix responded to excellent compressive strengths approaching $120 \mathrm{MPa}$ and exhibited good workability with a loss of slump-flow rate up to $33 \%$ after $60 \mathrm{~min}$. It also exhibited very low abrasion resistance $(0.5 \%)$, stable shrinkage and expansion rates (stabilization over 10 days), very low chloride diffusion coefficient (less than $0.1 \times 10^{-14} \mathrm{~m}^{2} / \mathrm{s}$ ) with a denser microstructure. This commercial UHPG (UHPG-120) has been developed to meet the needs of the market.
\end{abstract}

Keywords: silica fume; reactive ultra-fine fly ash; chloride diffusion coefficient; microscopic properties; cement-based grout

\section{Introduction}

Ultra-high-performance concrete (UHPC) is an innovative cement-based material with a minimum specified compressive strength of $120 \mathrm{MPa}$ [1-4]. UHPC, also known as reactive powder concrete, is formulated by combining Portland cement, supplementary cementitious materials, and reactive powders or fibers $[5,6]$. The matrix of UHPC is dense and has a minimal disconnected pore structure resulting in low permeability, superior durability, and compressive strength $[7,8]$. The inclusion of fibers in UHPC facilitates higher bond strength to enhance tensile and ductile behavior [8-10]. UHPC is used in precast components for construction, bridge components, and other special construction projects. In recent years, UHPC has increasingly been used in road and bridge engineering, repair and rehabilitation, and surface decoration in a variety of engineering fields. However, this material is relatively new (less than 30 years) and has been applied to a relatively small proportion of cement grouting composites. Cement grouting 
has been used in various areas of civil engineering, such as prefabricated structures, structural rehabilitation, expansion joint filling, and soil stabilization. The strength and workability of the grout are essential to the formation of prefabricated structures [11-13]. Ultra-high-performance grout (UHPG) materials are an ideal use of UHPC for use in precast construction, structural rehabilitation, soil stabilization, crack injection, and filling holes in concrete structures [14,15]. UHPG meets the needs of the market and the specificity of construction engineering while providing good mechanical properties and low emissions. These research and engineering applications imply a bright future for UHPG.

UHPG with a low water-to-binder ratio $(\mathrm{w} / \mathrm{b})$ requires superplasticizers to obtain the desired rheology to flow through joints and cracks (i.e., adequate flowability). Polycarboxylate superplasticizer (PS) powders are meant to improve the rheology of UHPG by improving the particle dispersion and improving flowability without significantly reducing the strength [16-18]. Attaining high-strength requirements requires the use of supplementary cementitious materials that are finer than cement particles [19-21]. Silica fume is highly efficient in improving the strength of grout and cement-based composites. The particle size of silica fume $(0.1$ to $0.2 \mu \mathrm{m})$ is approximately 100 to 200 times smaller than that of cement particles $(1.5$ to $160 \mu \mathrm{m})$ [22,23]. Silica fume is useful to improve early strength, as well as the mechanical properties and durability of cement-based materials. The disadvantage of silica fume is that it significantly reduces workability and flowability [24,25].

Reactive ultra-fine fly ash (RUFA) is a novel industrial by-product originating from thermal power plants (which burn coal at temperatures up to $1500{ }^{\circ} \mathrm{C}$ ) [26-28]. Its chemical composition is similar to that of fly ash; however, it provides a high specific surface area and a particle size $(0.5$ to $5 \mu \mathrm{m})$ approximately 10 to 20 times smaller than that of cement particles [26,27]. As a partial replacement for cement, RUFA has been shown to enhance the workability, mechanical properties, and durability of cement-based materials [26]. The ultra-fine spherical particles of RUFA provide efficient rheology. When mixed with cement and silica fume, RUFA can fill the gaps between the larger particles to optimize particle packing effects [26]. Therefore, a combination of cement, silica fume, and RUFA in appropriate amounts is expected to improve the rheology, mechanical properties, and durability of UHPG.

The UHPG mix (UHPG-120) presented in this study is a commercial product developed by our research team in collaboration with Triaxis Corporation (Changsha city, Hunan province, China) and is now commercially available in the general construction materials market. Due to commercial confidentiality considerations, this study is only an in-depth academic study of the commercially available product mixture and is intended as a reference for industry and academia. UHPG's general acceptance criteria for commercialization are based on workability and compressive strength, without in-depth investigation of the related mechanical properties, durability, and other engineering characteristics. In this study, an in-depth academic investigation of the product was carried out. A comparison was made with other studies published in the last few years on UHPC or UHPG to understand the strengths and weaknesses of the UHPG mixture. The aim of this study was to develop an eco-friendly hybrid composition for UHPG (comprising RUFA, silica fume, and cement) capable of providing reasonable strength and workability. This study also investigated the rheological behavior through a slump-flow test, volume stability through expansion and shrinkage tests, mechanical properties included compressive strength, flexural strength, and abrasion tests, as well as permeability through chloride migration and permeability tests of the hybrid UHPG. Scanning electron microscope (SEM) and mercury intrusion porosimetry (MIP) tests were then used to verify the microstructural behavior of the UHPG. Finally, we present practical engineering examples to verify the feasibility of this formulation for future commercial development. 


\section{Materials and Methods}

\subsection{Materials}

The binders used in this study consisted of four materials: ordinary Portland cement, rapid hardening sulphoaluminate cement, silica fume, and RUFA, all sourced from Triaxis Corporation(Triaxis, Changsha, China). Type-II Portland cement had a specific gravity of 3.15 and fineness of $3660 \mathrm{~cm}^{2} / \mathrm{g}$. Sulphoaluminate cement had a specific gravity of 2.98 and fineness of $4570 \mathrm{~cm}^{2} / \mathrm{g}$. Silica fume had a specific gravity of 2.20 and fineness of $225,000 \mathrm{~cm}^{2} / \mathrm{g}$. RUFA had a specific gravity of 2.61 and fineness of $22,400 \mathrm{~cm}^{2} / \mathrm{g}$. The chemical composition of the four cementitious materials is shown in Table 1 . The fine aggregate was natural river sand with saturated surface dry specific gravity of 2.77, absorption of $2.28 \%$, and fineness modulus of 2.55. PS powders produced by Triaxis Corporation with a high water-reducing rate were used as an admixture to control workability. The water content, active component, and bulk density of the PS powders were 3\%, 90\%, and $450 \mathrm{~kg} / \mathrm{m}^{3}$, respectively.

Table 1. The chemical composition of Portland cement, sulphoaluminate cement, silica fume, and RUFA.

\begin{tabular}{ccccc}
\hline \multirow{2}{*}{$\begin{array}{c}\text { Chemical } \\
\text { Composites }\end{array}$} & $\begin{array}{c}\text { Portland } \\
\text { Cement }\end{array}$ & $\begin{array}{c}\text { Sulphoaluminate } \\
\text { Cement }\end{array}$ & Silica Fume & RUFA \\
\cline { 2 - 5 } & \multicolumn{4}{c}{ Content (wt. \%) } \\
\hline $\mathrm{SiO}_{2}$ & 20.47 & 8.75 & 94.40 & 44.66 \\
$\mathrm{Al}_{2} \mathrm{O}_{3}$ & 4.54 & 33.80 & 0.53 & 24.83 \\
$\mathrm{Fe}_{2} \mathrm{O}_{3}$ & 3.28 & 1.76 & 0.14 & 6.18 \\
$\mathrm{CaO}$ & 63.47 & 42.95 & 1.35 & 12.47 \\
$\mathrm{MgO}$ & 2.18 & 1.91 & 0.48 & 4.22 \\
$\mathrm{SO}_{3}$ & 2.36 & 8.11 & 1.02 & 0.18 \\
others & 3.70 & 2.72 & 2.08 & 7.46 \\
\hline
\end{tabular}

\subsection{Mix Design and Testing Methods}

A low $\mathrm{w} / \mathrm{b}$ of 0.21 was used in the UHPG mixture. The binder-to-fine aggregates mass ratio was 1:1.17. Table 2 lists the mix design of UHPG. To create homogeneous mortar specimens, the binders and fine aggregate were mixed using a mixing machine in three phases, as follows:

- $180 \mathrm{~s}$ at low speed (136 rpm);

- $90 \mathrm{~s}$ at intermediate speed (281 rpm);

- $45 \mathrm{~s}$ at high speed (550 rpm).

Table 2. The mix design of the commercial UHPG $\left(\mathrm{kg} / \mathrm{m}^{3}\right)$.

\begin{tabular}{ccccccc}
\hline Water & $\begin{array}{c}\text { Portland Type } \\
\text { II Cement }\end{array}$ & $\begin{array}{c}\text { Sulphoaluminate } \\
\text { Cement }\end{array}$ & Silica Fume & RUFA & PS & $\begin{array}{c}\text { Fine } \\
\text { Aggregates }\end{array}$ \\
\hline 224 & 880 & 40 & 70 & 80 & 10 & 920 \\
\hline
\end{tabular}

Casting into metal molds began immediately after mixing was complete. After demolding $(6 \mathrm{~h})$, the specimens were air- and/or water-cured until the relevant testing age was reached. Table 3 presents details related to the tests performed, the dimensions of the specimens, curing conditions, and the standards used in this study. The results of each test were averaged from five specimens. 
Table 3. Test methods.

\begin{tabular}{|c|c|c|c|c|c|}
\hline \multicolumn{2}{|c|}{ Test Target } & \multirow{2}{*}{$\begin{array}{c}\text { Specimen } \\
\text { Dimensions (mm) } \\
-\end{array}$} & \multirow{2}{*}{$\begin{array}{c}\begin{array}{c}\text { Referenced } \\
\text { Standard }\end{array} \\
\text { ASTM C1437 }\end{array}$} & \multirow{2}{*}{$\begin{array}{c}\text { Testing Age } \\
\text { (Days) } \\
-\end{array}$} & \multirow{2}{*}{$\begin{array}{c}\begin{array}{c}\text { Curing } \\
\text { Conditions }\end{array} \\
-\end{array}$} \\
\hline Fresh properties & Slump-flow test & & & & \\
\hline \multirow{5}{*}{$\begin{array}{l}\text { Mechanical } \\
\text { properties }\end{array}$} & $\begin{array}{l}\text { Compressive } \\
\text { strength test }\end{array}$ & $50 \times 50 \times 50$ & ASTM C109 & $1,3,7,14,28$ & Air and water \\
\hline & Flexural strength & $40 \times 40 \times 160$ & ASTM C348 & 7,28 & Air and water \\
\hline & Expansion test & $\phi 50 \times 100$ & - & $1 \sim 28$ & Air \\
\hline & Abrasion test & $300 \times 300 \times 100$ & ASTM C779 & 28 & Air \\
\hline & $\begin{array}{c}\text { Drying shrinkage } \\
\text { test }\end{array}$ & $285 \times 25 \times 25$ & ASTM C596 & $2 \sim 28$ & Air \\
\hline \multirow[t]{2}{*}{ Permeability } & $\begin{array}{c}\text { Non-Steady-state } \\
\text { chloride migration } \\
\text { test }\end{array}$ & $\phi 100 \times 50$ & NT Build 492 & 7,28 & Water \\
\hline & $\mathrm{RCPT}$ & $\phi 100 \times 50$ & ASTM C1202 & 7,28 & Water \\
\hline \multirow{2}{*}{$\begin{array}{c}\text { Microstructure } \\
\text { observations }\end{array}$} & SEM observation & $10 \times 10 \times 3$ & ASTM C1723 & 28 & Water \\
\hline & MIP test & $10 \times 10 \times 3$ & ASTM D4404 & 28 & Water \\
\hline
\end{tabular}

The slump-flow test was carried out using a flow table manufactured by Chung Yenn Corporation in Taiwan. The paste was mixed and pounded into two layers to fill the flow mold. Without vibrating the flow table, the mold was pulled up vertically to allow the paste to flow freely for $60 \mathrm{~s}$ and then five slump-flow diameters were recorded and averaged. Compressive and flexural tests were carried out using a universal testing machine (SHIMADZU UH-1000KN) (Sanpany, Taipei, Taiwan) manufactured by Sanpany Corporation in Taiwan. For water curing specimens, the specimens were taken out of the curing tank before the test and kept to Saturated-surface-dry condition before the test. For air curing specimens, the test was carried out directly. After the specimen had been loaded to failure, the machine automatically recorded the maximum failure load and then calculated the test results according to the corresponding American Society for Testing and Material (ASTM) specification.

The shrinkage test equipment was purchased from Chung Yenn Corporation. After demolding, the specimen was placed on a test frame to measure the initial value (the test time was set to 0 days), then the test time was recorded continuously for 1-11 days, 18 days, and 25 days, and the corresponding changes were recorded. The expansion test was a self-made test device. The expansion test involved filling a cylindrical steel mold with a specimen to simulate the specimen being restrained around and at the bottom. A $2 \mathrm{~mm}$-thick plastic plate was placed on top of the specimen, on which a micrometer was mounted to measure the expansion at the top edge of the specimen (as shown in Figure 1). After the installation of the test device, the expansion was measured, and the test time was set to $0 \mathrm{~h}$. The test time was recorded continuously for 1-6 h and 1-28 days, and the corresponding changes were recorded.

The abrasion test, non-steady-state chloride migration test, and rapid chloride permeability test (RCPT) were designed regarding the test specifications and were also self-made test devices. The abrasion test was carried out using Procedure A of ASTM C779 (ChungYenn, New Taipei City, Taiwan), with three abrasive discs attached to the surface of the specimens. The abrasive discs were rotated at $280 \mathrm{rpm}$ when the machine was started, and each disc produced a uniform load of $22 \mathrm{~N}$. The test time was $30 \mathrm{~min}$. At the end of the test, the surface was cleaned of dust, and the amount of wear was measured. Before the RCPT, the lateral surface of the specimen was coated with epoxy and placed in the vacuum desiccator with the pressure of $1 \mathrm{~mm} \mathrm{Hg}(133 \mathrm{MPa})$ for $6 \mathrm{~h}$, followed by immersion in deionized water for $24 \mathrm{~h}$ before testing. The volume of the two test cells was $250 \mathrm{~mL}$, and the power supply was applied with $60 \mathrm{~V}$ direct current to the test. The anode cell was filled with $0.3 \mathrm{~N} \mathrm{NaOH}$ solution, and the cathode cell was filled with $3 \% \mathrm{NaCl}$ solution. The 
current was recorded every $30 \mathrm{~min}$ during the 6-hour test. The total charge-passed was obtained by integrating the current with the time of the voltage application according to the ASTM standard formula. The specimens of the non-steady-state chloride migration test were prepared in the same way as that of RCPT. The volume of the cathode cell with a $10 \% \mathrm{NaCl}$ solution was $12 \mathrm{~L}$, and the anode cell with a $0.3 \mathrm{~N} \mathrm{NaOH}$ solution was $300 \mathrm{~mL}$. The initial direct current voltage of the test equipment is $30 \mathrm{~V}$. Following the initial voltage corresponding to the output initial current, the test voltage and the test duration were then corrected by reference to the requirements of the NT Build 492. After completion of the test, the specimen was split longitudinally, and a $0.1 \mathrm{M}$ silver nitrate solution was sprayed onto the surface of the specimens. The depth of the penetration was determined by the change in color. The average penetration depth (averaged over 10 points) was then used to calculate the chloride diffusion coefficient by referring to Fick's second law (see NT Build 492 for details).

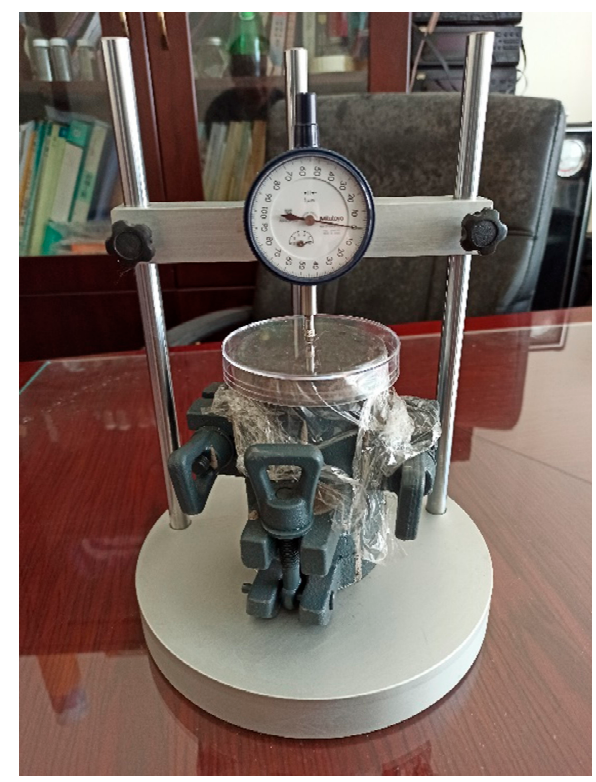

Figure 1. The expansion test instrument.

The microscopic tests included MIP measurements and SEM observations. The MIP instrument (AutoPore IV 9500) (Micromeritics, Downers Grove, Illinois, America) was manufactured by Micromeritics Corporation in America, and the maximum pressure of $33,000 \mathrm{psi}$ can be exerted. The pore size using the MIP instrument ranged from $3 \mathrm{~nm}$ to $100,000 \mathrm{~nm}$. Specimens were dried and left in the desiccator until the MIP test. The SEM instrument (JSM-IT100) (JEOL, Tokyo, Japan) was manufactured by JEOL Corporation in Japan. After drying for $24 \mathrm{~h}$, the specimens were vacuumed, and Au ion-sputtered for SEM observation and different magnifications $(\times 1000,3000$ and 5000) were used to observe the surface condition of the microstructures of the UHPG.

\section{Results and Discussion}

\subsection{Slump-Flow Test}

Slump testing was performed to verify the workability and flowability of UHPG. The mortar was poured into a copper ring in accordance with ASTM C1437 specifications and then pulled up vertically to measure the slump-flow diameter of the mortar. The mortar was then left to stand for $15,30,45$, and $60 \mathrm{~min}$, during which the corresponding slump-flow diameters were measured. These values were used to measure the loss of slump-flow over a period of $60 \mathrm{~min}$ for use as a reference. Test results are listed in Table 4, and photographs of the slump-flow at 0, 15, 30, 45, and $60 \mathrm{~min}$ are presented in Figure 2. 
Table 4. Slump-flow test results.

\begin{tabular}{cccccccc}
\hline & \multicolumn{5}{c}{ Slump-Flow $(\mathbf{m m}) \mathbf{1}^{\mathbf{1}}$} \\
\cline { 2 - 7 } Time (min) & $\mathbf{1}$ & $\mathbf{2}$ & $\mathbf{3}$ & $\mathbf{4}$ & $\mathbf{5}$ & $\begin{array}{c}\text { Standard } \\
\text { Deviation }\end{array}$ \\
\cline { 2 - 8 } & 323 & 318 & 313 & 320 & 316 & 318 & 3.41 \\
15 & 265 & 257 & 257 & 257 & 260 & 259 & 3.12 \\
30 & 246 & 244 & 244 & 246 & 245 & 245 & 0.89 \\
45 & 228 & 225 & 224 & 227 & 226 & 226 & 2.41 \\
60 & 216 & 213 & 213 & 218 & 213 & 2.06 \\
\hline
\end{tabular}

${ }^{1}$ Testing room temperature was $18.6^{\circ} \mathrm{C}$, and mixing water temperature was $15.3^{\circ} \mathrm{C}$.

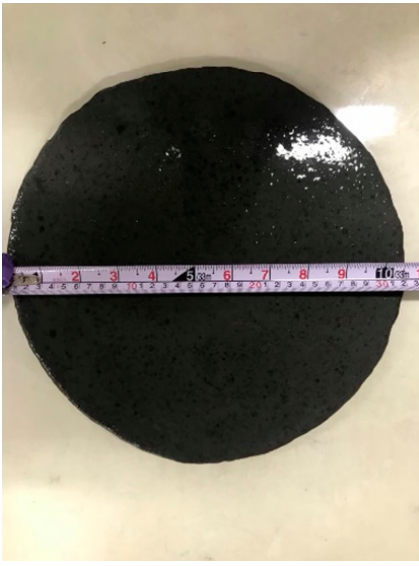

(a)

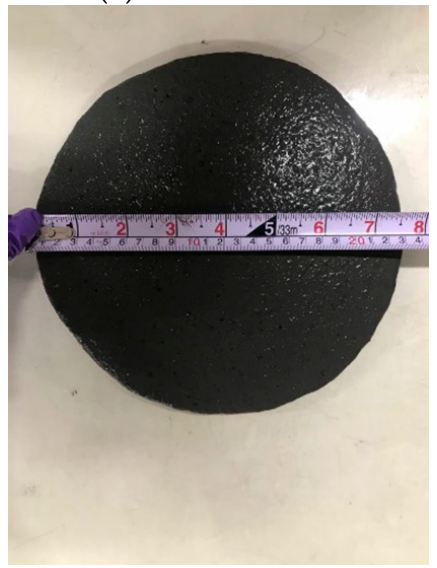

(d)

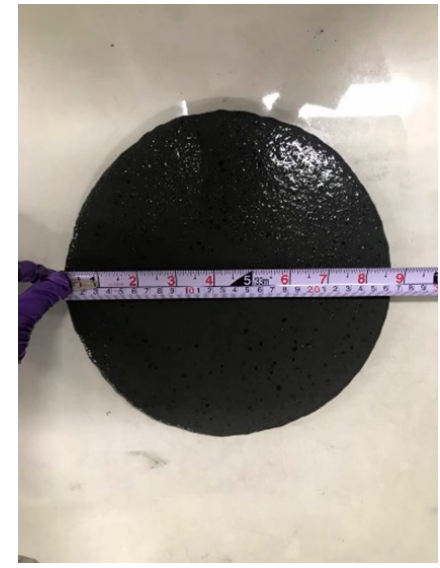

(b)

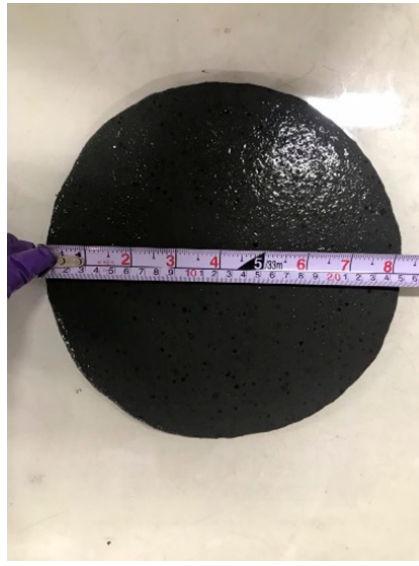

(c)

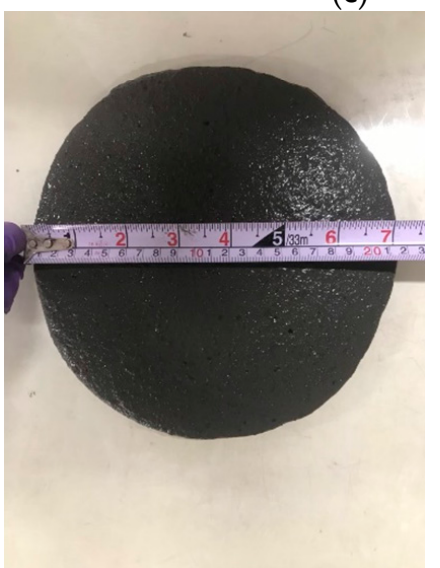

(e)

Figure 2. Photographs of slump-flow test results: (a) $0 \mathrm{~min}$; (b) $15 \mathrm{~min}$; (c) $30 \mathrm{~min}$; (d) $45 \mathrm{~min}$; (e) $60 \mathrm{~min}$.

The initial slump-flow was $318 \mathrm{~mm}$. When left to stand for $60 \mathrm{~min}$, the UHPG retained a slump-flow of $215 \mathrm{~mm}$, which is significantly better than UHPC or cement grout (initial slump-flow is between 180-200 $\mathrm{mm}$ ) [29]. It was evident that the UHPG mixture developed in this study has excellent flow properties. Previous studies have shown that the inclusion of silica fume tends to reduce flowability, while the inclusion of RUFA tends to increase flowability [30]. The spherical particles of fly ash and silica fume contributed to the flow behavior of the pastes, as shown in Figure 3. The ultra-fine particles of both materials have limited benefits in terms of improving flowability. As a result, PS plays an important role in the flow behavior of UHPG. As mentioned in previous studies [17,18,31], the PS exhibited better fluidity properties and delayed the process of hydration. The addition of PS allowed UHPG to maintain a slump-flow of $215 \mathrm{~mm}$ with only about $33 \%$ loss of slump-flow after $60 \mathrm{~min}$. The results confirmed that UHPG outperformed the initial slump-flow of other 
UHPCs $[17,18,29-31]$. The best rheological behavior was achieved with a PS dosage of $0.93 \%$ of the binders in this study.

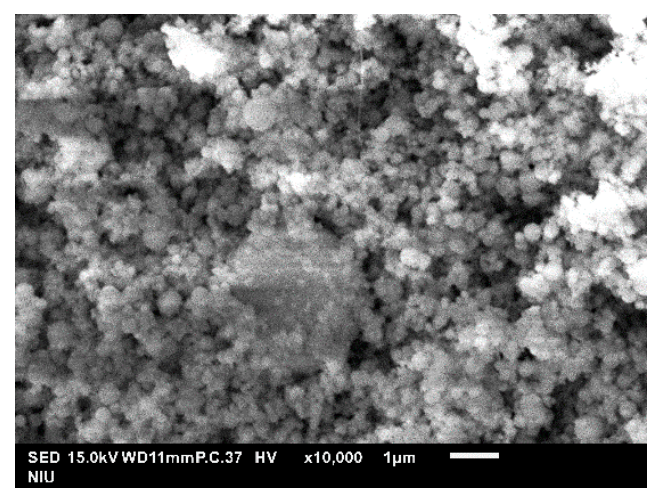

(a)

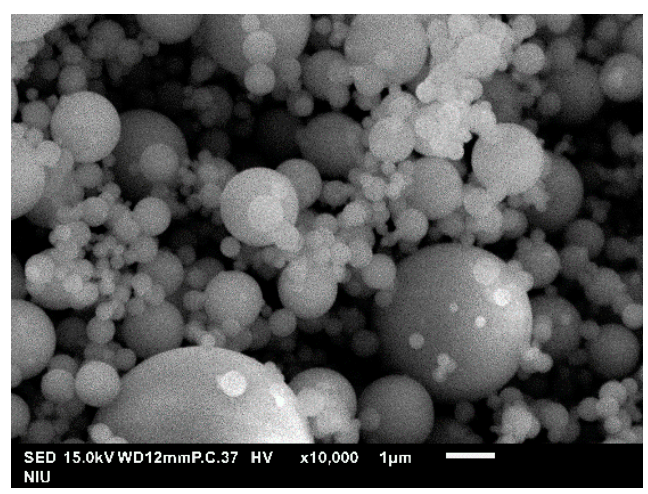

(b)

Figure 3. SEM photos (10,000× magnification): (a) silica fume; (b) RUFA.

\subsection{Compressive Strength}

Figure 4 presents compressive strength histograms of UHPG specimens under water and air curing. Overall, the compressive strength increased with curing age, and specimens that underwent water curing achieved strength values higher than those obtained under air curing. In the first curing stage (i.e., 1 day), the compressive strength of the water-cured specimens was approximately $19 \%$ higher than that of the air-cured specimens. Water curing resulted in one-day strength of more than $60 \mathrm{MPa}$, which represents good earlystrength development. The packing density of silica fume particles and RUFA is crucial to the high-strength requirements of UHPG. Ultra-fine silica fume and RUFA contributed to the formation of calcium-silicate-hydrates (C-S-H) colloids, resulting in an excellent compressive strength of close to $120 \mathrm{MPa}$ at 28 days [32]. The optimal UHPG mixture comprised $6.5 \%$ silica fume and $7.4 \%$ RUFA as a replacement for cement in this study.

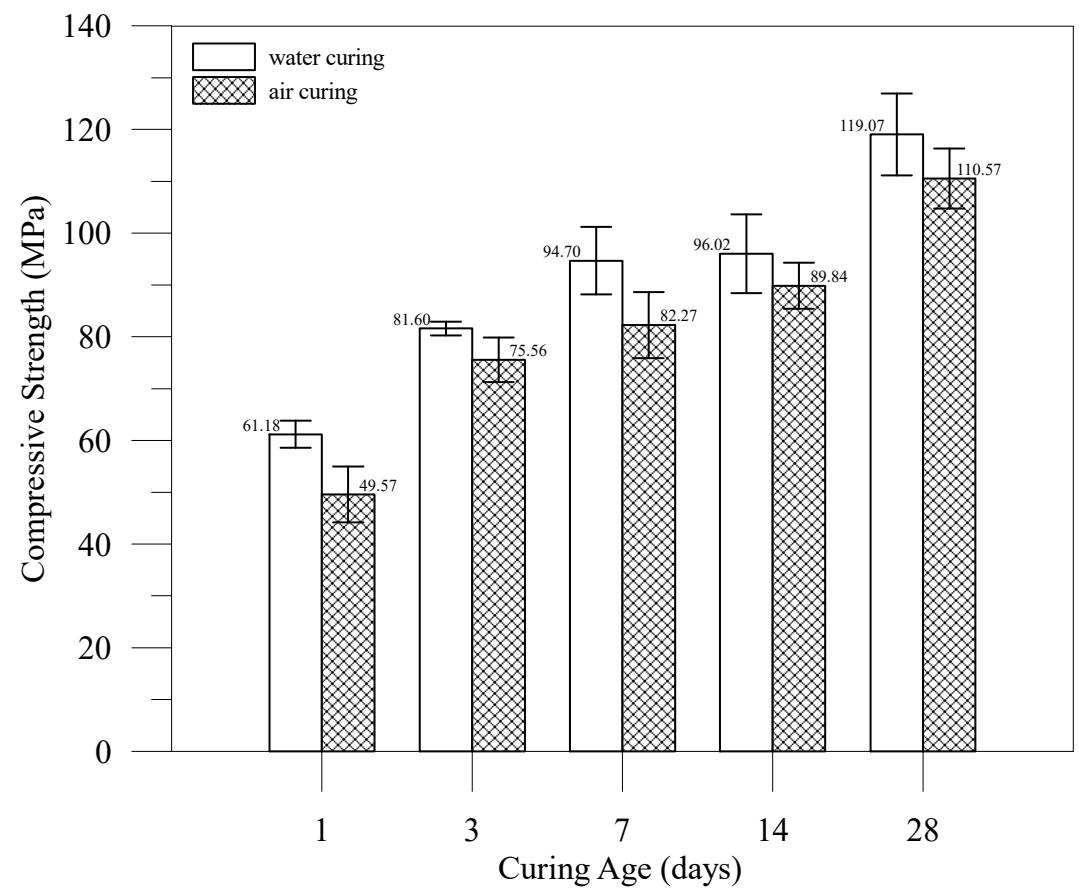

Figure 4. Histograms showing the compressive strength development. 
From the perspective of density, the optimal particle packing effects were achieved using large cement particles with medium RUFA particles and small silica fume particles as cementitious materials. The RUFA and silica fume particles were shown to fill the gaps between the cement particles, resulting in a denser paste microstructure and excellent compressive strength. John confirmed that the addition of nanoparticles to concrete can improve the compressive strength and the density of microstructures [33]. Several researchers have reported that the degree of cement hydration and the particle packing density of the matrix play important roles in the strength development of UHPC [26,34,35]. Our results confirmed that ultra-fine spherical particles can enhance the compressive strength of UHPG [34-37].

\subsection{Flexural Strength and Abrasion Resistance}

Figure 5 presents flexural strength histograms of UHPG specimens under water and air curing at 7 and 28 days. The flexural strength of UHPG was lower than the compressive strength and the flexural resistance of general UHPC. In this study, the mixture of UHPG without fibers or coarse aggregates resulted in poor flexural strength. Flexural strength appeared to follow the same trend as compressive strength under both curing conditions. UHPG specimens exhibited flexural strength lower than that of typical cement grouting materials (approximately $4 \mathrm{MPa}$ at 28 days) [32].

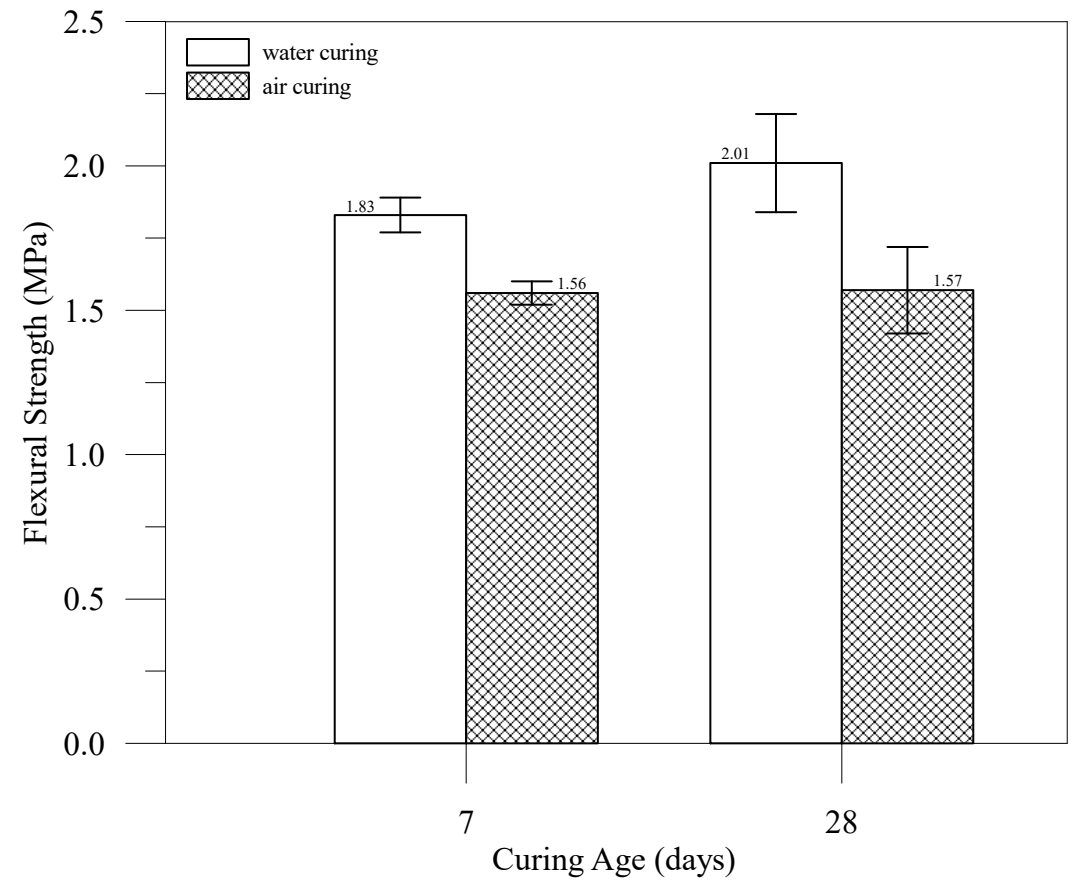

Figure 5. Histograms of flexural strength.

Table 5 lists the abrasion test results obtained at 7 and 28 days. The abrasion rate of UHPG was controlled to less than $0.5 \%$, and the depth of abrasion was low (around $0.2-0.4 \mathrm{~mm}$ ). The abrasion resistance of UHPG was superior to that of ordinary cement grouting materials, and the abrasion properties were similar to those of UHPC with fibers [32]. This confirmed that the ultra-fine particles had a significant effect on compressive strength and abrasive resistivity but not on flexural strength. The small particles of RUFA filled spaces among the cement grains, silica fume particles, and fine aggregate, resulting in surface microstructures of higher density and strength. It appears that a suitable quantity of fine particles functioning as cement filler can achieve the same abrasion resistance as UHPC with coarse aggregates and fibers [38-40]. 
Table 5. Abrasion test results.

\begin{tabular}{ccc}
\hline Age & Abrasion Rate & Standard Deviation \\
\hline 7 days & $0.506 \%$ & $0.002 \%$ \\
28 days & $0.512 \%$ & $0.005 \%$ \\
\hline
\end{tabular}

\subsection{Volumetric Stability}

We expected that dosing UHPG with ultra-fine silica fume and RUFA particles (i.e., a large specific surface area) would accelerate hydration when exposed to water. Expansion tests and dry shrinkage tests were used to observe the volumetric stability of the specimens. The results of volumetric stability were expressed as the average of the five sets of test measurements with a coefficient of variation of less than $5 \%$.

The expansion test was performed in two parts. We first observed the expansion between casting and final setting (every hour over a period of $6 \mathrm{~h}$ ) and then made daily observations over a period of 28 days. The results of the first stage are shown in Figure 6 . We can see that expansion increased significantly with setting time, eventually reaching $364 \times 10^{-6}$ at $6 \mathrm{~h}$. This result may have been due to the inclusion of sulphoaluminate cement, which is characterized by rapid setting (final setting time was four hours). Researchers have proposed the use of sulphoaluminate cement in combination with ordinary Portland cement to improve early strength development [41,42]; however, the formation of ettringite tended to enhance expansion. The inclusion of silica fume in the UHPG mixture should also promote rapid hydration due to the reaction of silica with calcium to form C-S-H gel, leading to significant initial expansion.

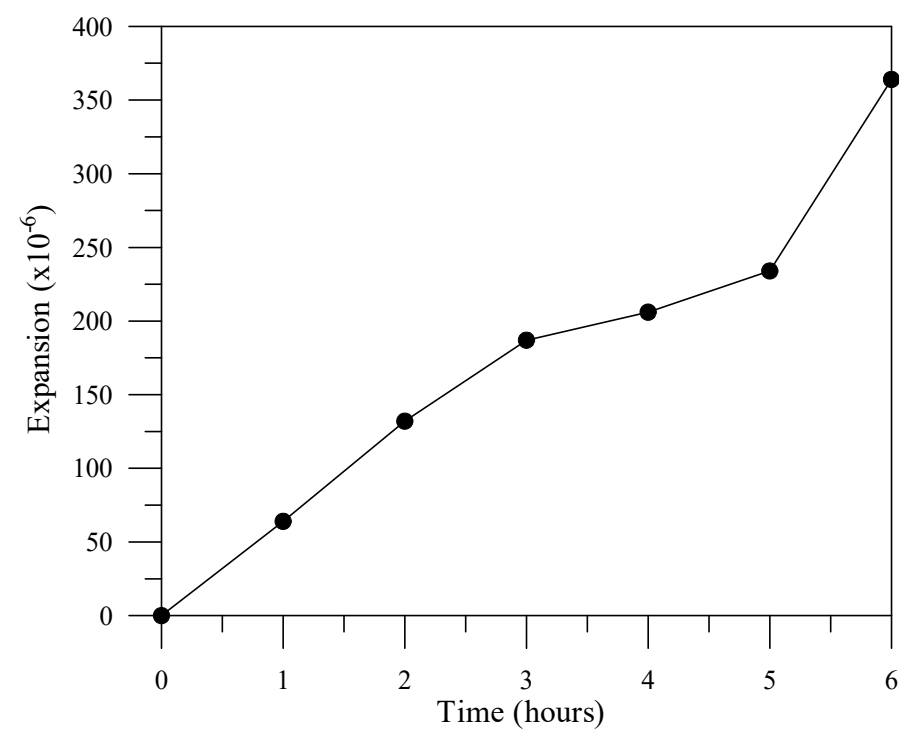

Figure 6. Expansion curve (prior to hardening).

Figure 7 presents the expansion curve for 1 to 28 days. Overall, the rate of expansion decreased with time. By 10 days, the specimen presented a steady expansion of roughly $338 \times 10^{-6}$. Previous studies have noted the effects of fine silica fume particles on the hydration of $\mathrm{C}_{3} \mathrm{~A}$ in UHPC [43-46]. The inclusion of RUFA reduced the heat of the hydration reaction, resulting in slower expansion [24,47]. The increased shrinkage caused by the addition of silica fume was counteracted by the expansion behavior, resulting in a tendency towards stabilization [46]. Figure 8 presents the results of shrinkage tests performed in accordance with ASTM C596 standards. Shrinkage increased with time but stabilized within 10 days (approx. 150-160 $\times 10^{-6}$ ). The results of shrinkage testing presented trends similar to those of the expansion test [48]. The UHPG specimens exhibited significantly lower shrinkage compared to previous results obtained from UHPC $[49,50]$. The shrinkage of the UHPG specimens was close to that of UHPC specimens containing shrinkage-reducing admixtures (approx. $200 \times 10^{-6}$ ) [49-52]. As a result, the shrinkage of the UHPG mixed 
with RUFA and silica fume was very low (i.e., good volume stability). Figure 9 presents a UHPG plate measuring $1.2 \mathrm{~m}$ in length, $2.4 \mathrm{~m}$ in width, and $13 \mathrm{~mm}$ in thickness (cast over a period of 90 days). The complete lack of surface cracking confirmed the volumetric stability of the UHPG.

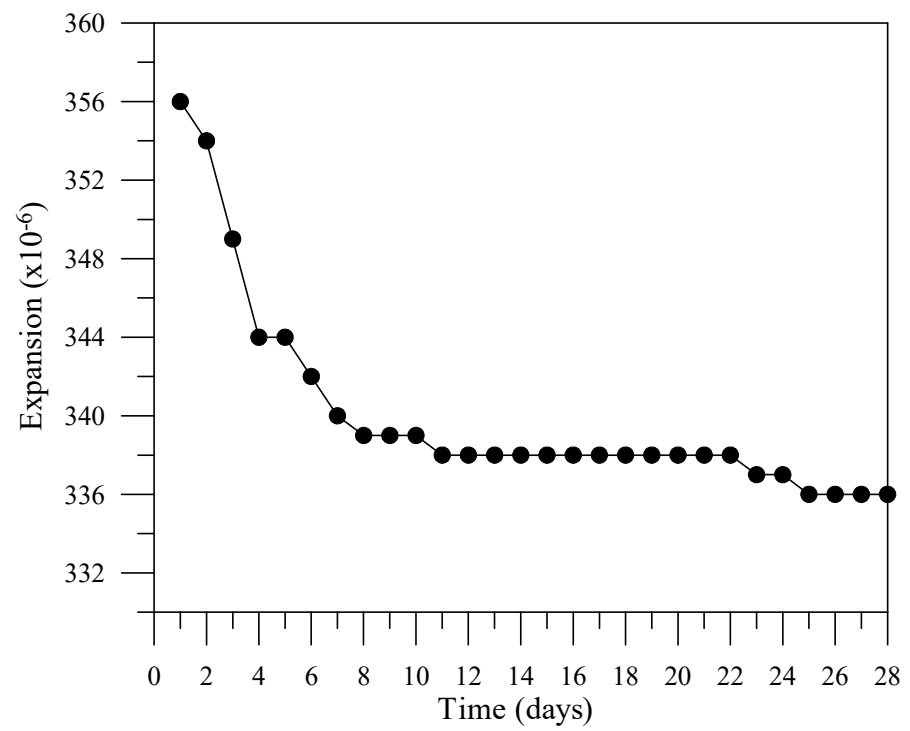

Figure 7. Expansion curves as a function of time.

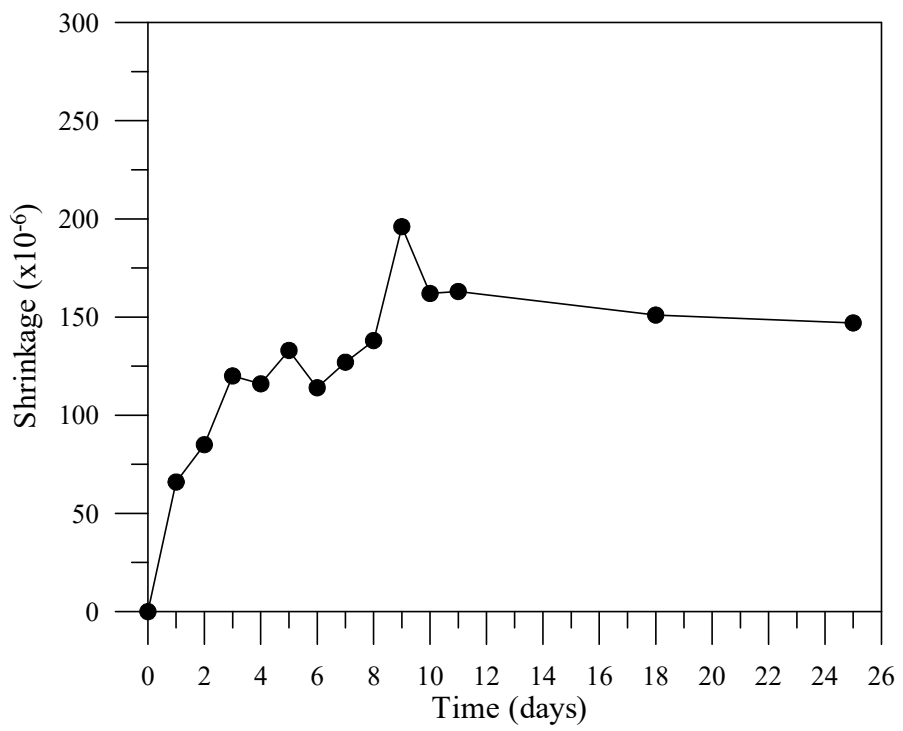

Figure 8. Shrinkage curve as a function of time. 


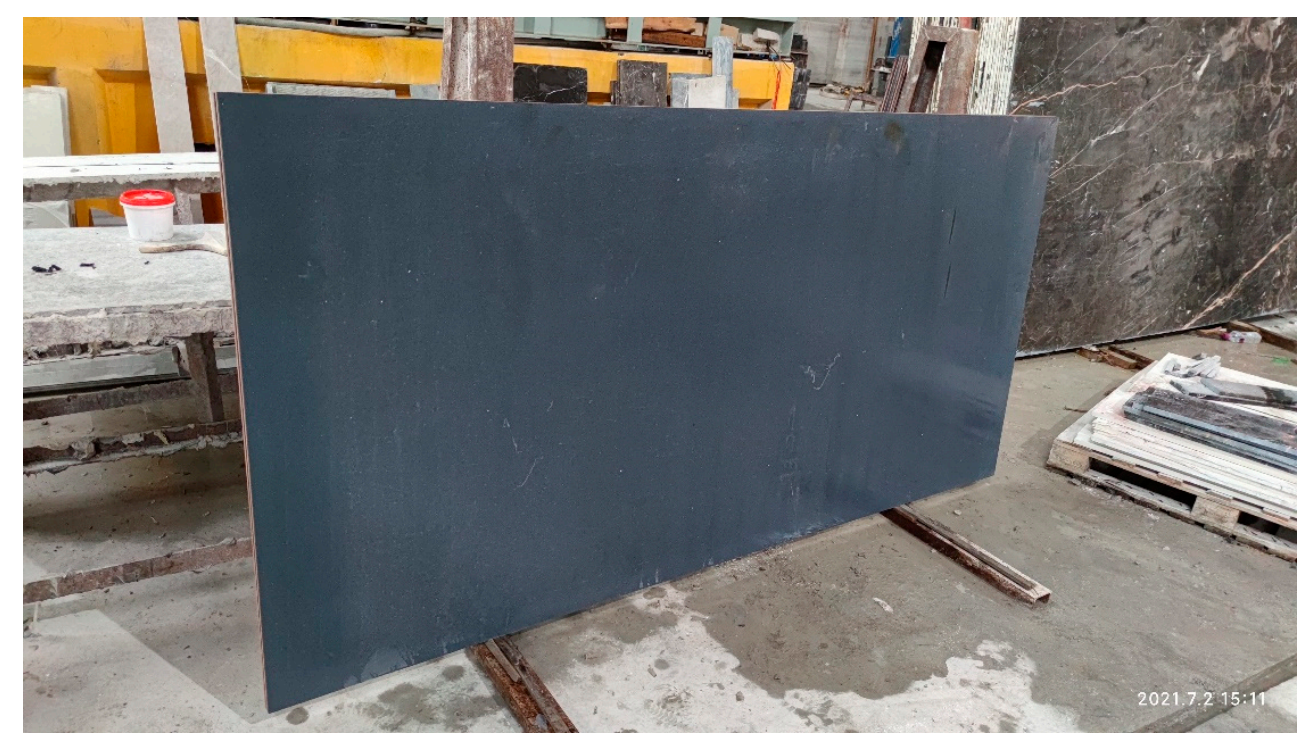

Figure 9. UHPG plate measuring $1.2 \mathrm{~m} \times 2.4 \mathrm{~m} \times 13 \mathrm{~mm}$.

\subsection{Permeability}

The permeability of UHPG was assessed in terms of chloride migration and the RCPT, as shown in Figure 10. Both tests revealed low chloride permeability. According to ASTM C1202, penetration of between 100 and 1000 coulombs is classified as 'very low' permeability, and below 100 coulombs is classified as 'negligible' [53]. Thus, the 7-day value (759 coulombs) indicated very low permeability, and the 28 -day value (69 coulombs) implied a negligible permeability. The RCPT results were much lower than those reported by previous studies $[54,55]$. Specifically, our results matched those of Tai, which were also below 100 coulombs [56]. These results confirmed that the ultra-fine particles contributed significantly to reducing the permeability of chlorine ions.

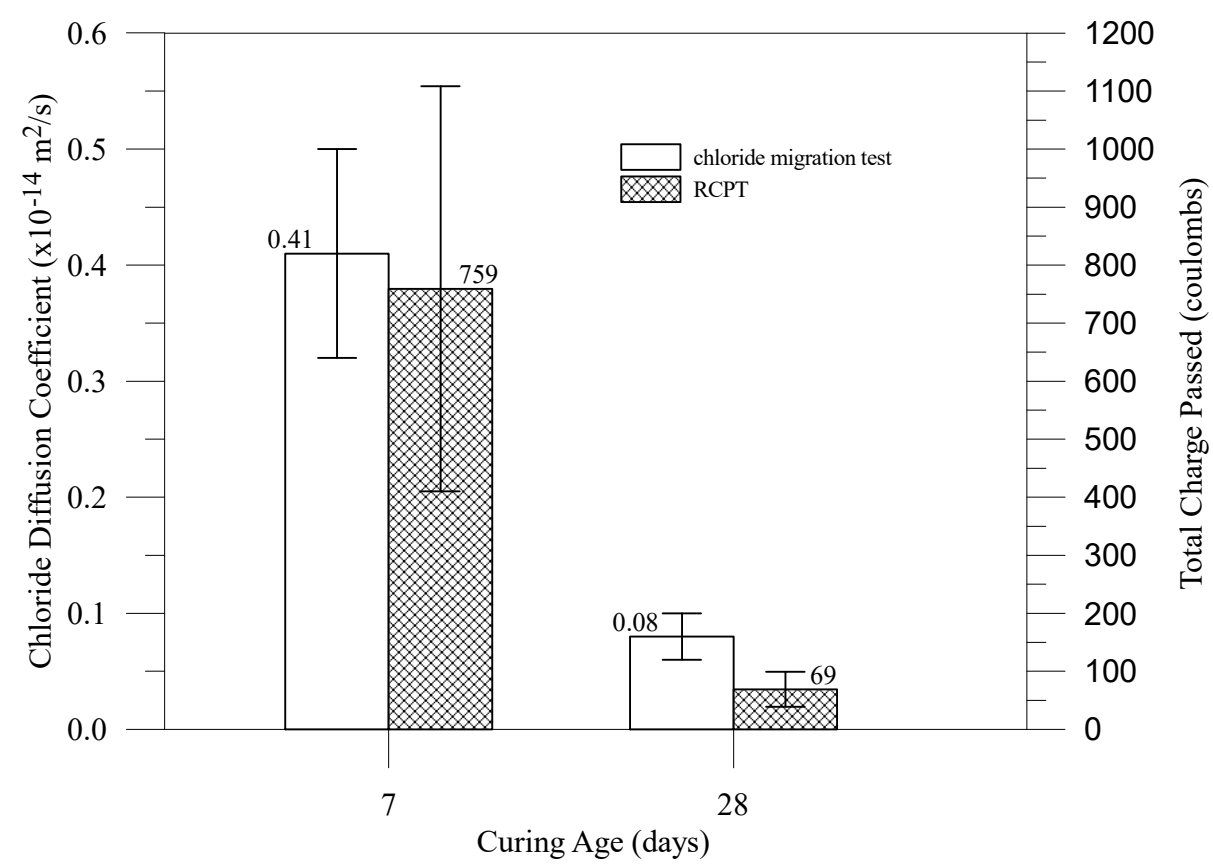

Figure 10. The results of the chloride migration test and RCPT.

According to Teng's assessment criteria for diffusion coefficient resistance to chloride [57], a 28-day diffusion coefficient of less than $2.5 \times 10^{-12} \mathrm{~m}^{2} / \mathrm{s}$ can be classified as extremely high in terms of resistance to chloride ingress. In our study, the diffusion 
coefficients of $0.41 \times 10^{-14} \mathrm{~m}^{2} / \mathrm{s}$ and $0.08 \times 10^{-14} \mathrm{~m}^{2} / \mathrm{s}$ for 7 and 28 days were significantly lower than in the study by Teng [57]. They were also significantly lower than those of UHPC $[54,58]$. It appears the fine RUFA and silica fume particles increased particle packing effects within the specimens. The finer particles consumed a larger quantity of calcium hydroxide to produce C-S-H colloids during hydration, which helped to improve the compactness of the mortar and reduce permeability. We found that UHPG containing ultra-fine particles far outperformed plain UHPC specimens containing fibers $[5,54,58,59]$. The fibers enhanced the tensile strength and toughness of UHPC but weakened the interfacial transition zone and increased the chloride diffusion coefficient. By contrast, ultra-fine particles strengthened the interfacial transition zone and significantly reduced permeability [59]. Taken together, it appears that ultra-fine particles played a key role in the permeability and microstructure of the UHPG.

\subsection{Observations of Microstructure}

The effect of ultra-fine particles on the microstructure of the UHPG specimens was observed using MIP tests and SEM. Figure 11 presents the MIP results of UHPG and ordinary Portland concrete (OPC) with compressive strength of $40 \mathrm{MPa}$ as reference. The cumulative intrusion of mercury and total porosity of the UHPG specimens were significantly lower than those of the OPC specimen. UHPG exhibited the lowest cumulative intrusion of $0.0359 \mathrm{~mL} / \mathrm{g}$, which is approximately $68 \%$ less than that of OPC $(0.115 \mathrm{~mL} / \mathrm{g})$. The lowest porosity of the UHPG specimen was $8.59 \%$, which is approximately $67 \%$ that of the OPC specimen $(26.38 \%)$. This shows that the addition of ultra-fine particles can reduce the connectivity between pores, increase density, and reduce porosity. Our results also verified that the inclusion of silica fume and RUFA in UHPG generated a secondary reaction with calcium hydroxide to produce a denser C-S-H colloid, thereby reducing the amount of free calcium hydroxide and reducing the volume and size of the pores caused by C-S-H colloids. Overall, this reduced the permeability of the UHPG. These results are similar to those of UPHCs with ultra-fine particulate binders $[60,61]$. The cumulative intrusion was significantly lower than that of UHPC containing fibers [62-64]. These results confirmed that silica fume has higher pozzolanic activity and faster reaction in the early stages, whereas the filler effects and superior pozzolanic activity of RUFA tend to refine the pore structure of UHPG mixtures at later stages.

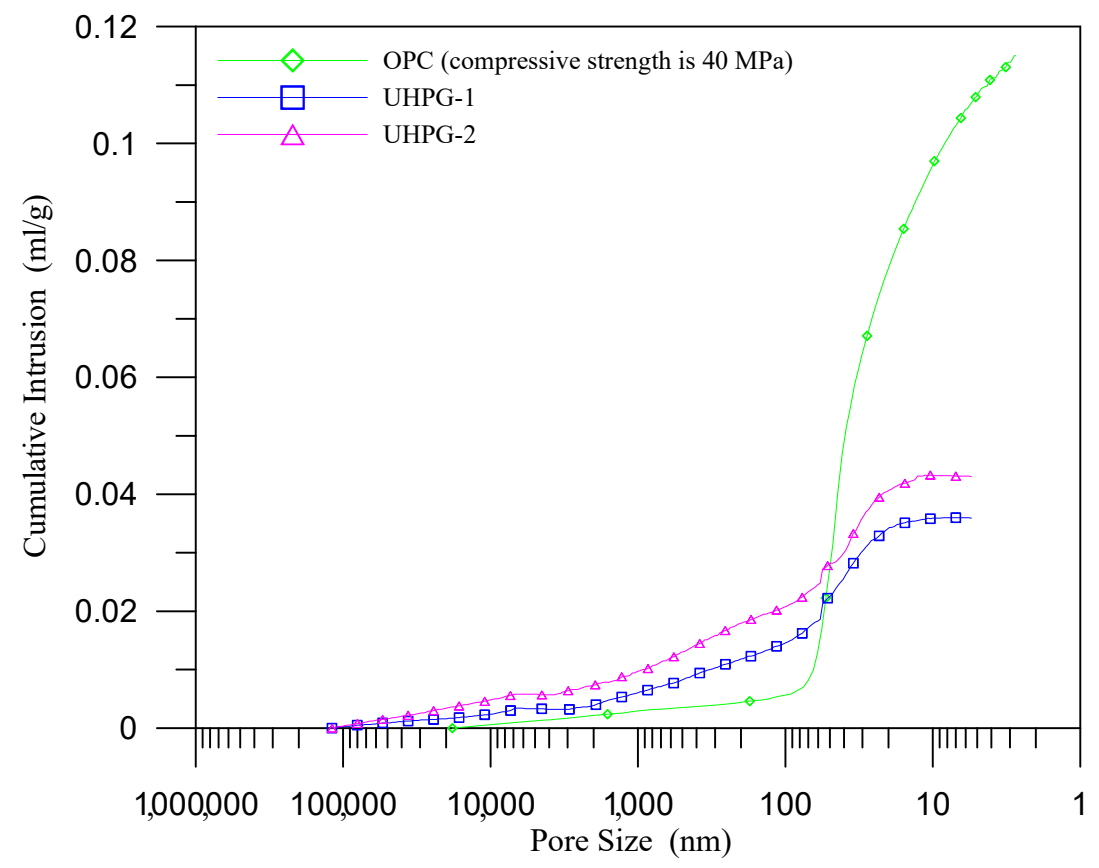

Figure 11. Pore size distributions of UHPG and OPC. 
Figure 12 presents SEM images of UHPG pastes at 28 days. As shown in Figure 12a to $12 \mathrm{c}$, ultra-fine particles were randomly distributed in the cement pastes; however, nonreacted RUFA was retained in the pastes, as shown in Figure 12c. We observed significantly less surface porosity and hydration reactants filling in the surface microstructure of UHPG paste. The inclusion of ultra-fine particles, such as silica fume and RUFA, had a positive effect on the densification of UHPG, which corresponds to the results described in the previous section. Needle-shaped AFt and C-S-H phases can be seen in Figure 12a,c. RUFA and sulphoaluminate cement with high alumina content contributed to the formation of these colloids, which appear to have improved the densification of the microstructure.

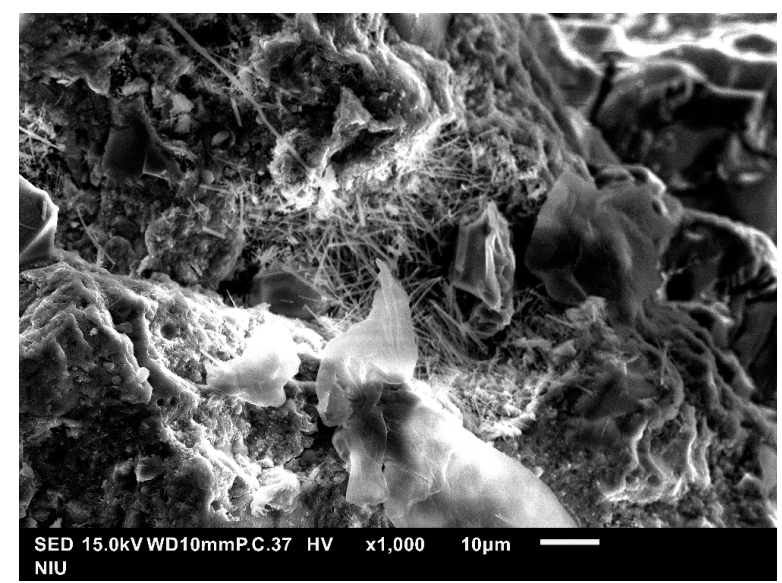

(a)

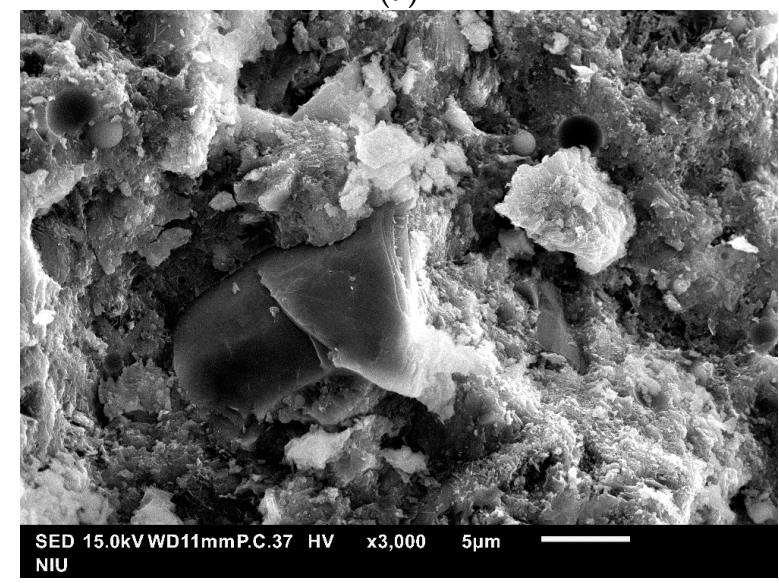

(b)

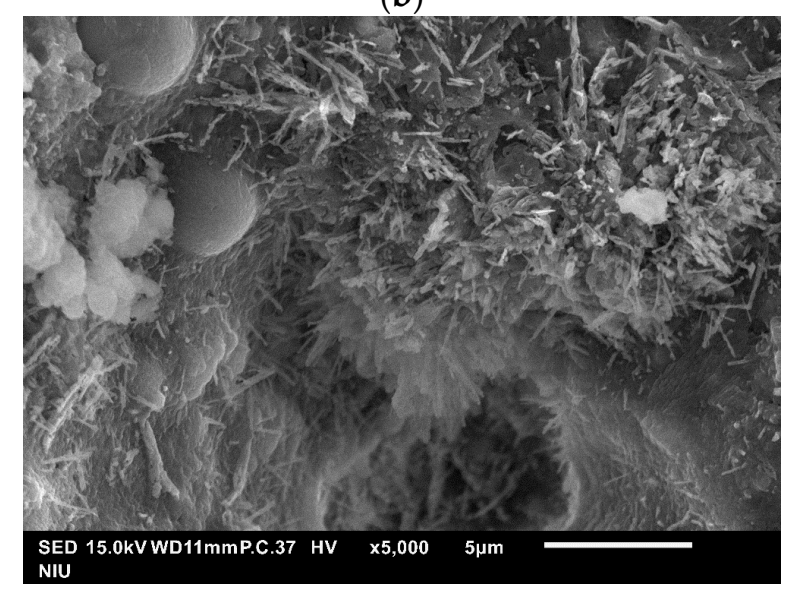

(c)

Figure 12. SEM images of UHPG pastes: (a) $\times 1000$ magnification; $(\mathbf{b}) \times 3000$ magnification; (c) $\times 5000$ magnification. 


\section{Conclusions}

This study demonstrated a commercial UHPG material formulated with ultra-fine particles, including silica fume and RUFA mixed with Type-II Portland cement and sulphoaluminate cement. PS powders ( $0.93 \mathrm{wt} . \%$ of binders) were used as an admixture to optimize workability. The optimal UHPG mixture comprised $6.5 \mathrm{wt} . \%$ silica fume and $7.4 \mathrm{wt} . \%$ RUFA as a replacement for cement. The resulting mixture exhibited excellent fluidity and compressive strength (up to $120 \mathrm{MPa}$ at 28 days). The inclusion of sulphoaluminate cement and silica fume helped to accelerate hardening ( $4 \mathrm{~h}$ for final setting) and early-strength development (1-day compressive strength over $60 \mathrm{MPa}$ ). The addition of silica fume and RUFA helped to improve the volumetric stability and densification of the material. Resistance to chlorine ions and pore volume were both far better than those of ordinary UHPC. Our results indicate that the ultra-fine spherical particles are significantly beneficial to the rheology, mechanical properties, and microstructures of UHPG. The proposed UHPG has excellent commercial applicability, including thin slabs and plates, cement grouts, and other grouting applications.

Author Contributions: Conceptualization, W.-T.L. and J.-S.Y.; methodology, W.-T.L. and A.C.; validation, W.-Q.Z. and Y.-H.C.; investigation, W.-Q.Z. and Y.-H.C.; resources, J.-S.Y.; data curation, W.-T.L., W.-Q.Z., and Y.-H.C.; writing-original draft preparation, W.-T.L.; writing-review and editing, W.-T.L.; visualization, W.-T.L. and A.C.; supervision, W.-T.L.; project administration, W.-T.L.; funding acquisition, J.-S.Y. All authors have read and agreed to the published version of the manuscript.

Funding: This research was funded by TRIAXIS Co., Ltd. (www.triaxis.com.tw, accessed on 8 August 2021), grant number 109A5063 in National Ilan University in Taiwan.

Institutional Review Board Statement: Not applicable.

Informed Consent Statement: Not applicable.

Data Availability Statement: Not applicable.

Acknowledgments: This research was supported by the Ministry of Science and Technology (MOST) in Taiwan under the Grant MOST 109-2221-E-197-001-MY2.

Conflicts of Interest: The authors declare no conflict of interest.

$\begin{array}{ll}\text { Abbreviations } \\ \text { ASTM } & \text { American Society for Testing and Material } \\ \text { C-S-H } & \text { calcium-silicate-hydrates } \\ \text { MIP } & \text { mercury intrusion porosimetry } \\ \text { OPC } & \text { ordinary Portland concrete } \\ \text { PS } & \text { Polycarboxylate superplasticizer } \\ \text { RCPT } & \text { rapid chloride permeability test } \\ \text { RUFA } & \text { reactive ultra-fine fly ash } \\ \text { SEM } & \text { scanning electron microscope } \\ \text { UHPC } & \text { ultra-high-performance concrete } \\ \text { UHPG } & \text { ultra-high-performance grout } \\ \text { w/b } & \text { water-to-binder ratio }\end{array}$

\section{References}

1. Liu, J.; Jin, H.; Zhao, X.; Wang, C. Effect of Multi-Walled Carbon Nanotubes on Improving the Toughness of Reactive Powder Concrete. Materials 2019, 12, 2625. [CrossRef]

2. Wan, L.; Wendner, R.; Liang, B.; Cusatis, G. Analysis of the behavior of ultra high performance concrete at early age. Cem. Concr. Compos. 2016, 74, 120-135. [CrossRef]

3. Wu, Z.; Shi, C.; Khayat, K.H. Investigation of mechanical properties and shrinkage of ultra-high performance concrete: Influence of steel fiber content and shape. Compos. B Eng. 2019, 174, 107021. [CrossRef]

4. $\quad \mathrm{Wu}$, Z.; Khayat, K.H.; Shi, C.; Tutikian, B.F.; Chen, Q. Mechanisms underlying the strength enhancement of UHPC modified with nano-SiO 2 and nano-CaCO 3 . Cem. Concr. Compos. 2021, 119, 103992. [CrossRef] 
5. Pourjahanshahi, A.; Madani, H. Chloride diffusivity and mechanical performance of UHPC with hybrid fibers under heat treatment regime. Mater. Today Commun. 2021, 26, 102146. [CrossRef]

6. Wille, K.; Kim, D.J.; Naaman, A.E. Strain-hardening UHP-FRC with low fiber contents. Mater. Struct. 2011, 44, 583-598. [CrossRef]

7. Li, Y.; Tan, K.H.; Yang, E.H. Influence of aggregate size and inclusion of polypropylene and steel fibers on the hot permeability of ultra-high performance concrete (UHPC) at elevated temperature. Constr. Build. Mater. 2018, 169, 629-637. [CrossRef]

8. Bajaber, M.A.; Hakeem, I.Y. UHPC evolution, development, and utilization in construction: A review. J. Mater. Res. Technol. 2021, 10, 1058-1074. [CrossRef]

9. Abbas, S.; Nehdi, M.L.; Saleem, M.A. Ultra-high performance concrete: Mechanical performance, durability, sustainability and implementation challenges. Int. J. Concr. Struct. Mater. 2016, 10, 271-295. [CrossRef]

10. Alkaysi, M.; El-Tawil, S.; Liu, Z.; Hansen, W. Effects of silica powder and cement type on durability of ultra high performance concrete (UHPC). Cem. Concr. Compos. 2016, 66, 47-56. [CrossRef]

11. Guo, H.; Tang, Z.; Liu, Q.; Xu, J.; Wang, M.; Liang, R.; Sun, G. Ultra-stable anti-washout cement grout achieved by super water absorbing villus-like nanocomposite hydrogel. Constr. Build. Mater. 2021, 301, 124035. [CrossRef]

12. Lacerda, M.M.S.; da Silva, T.J.; Alva, G.M.S.; de Lima, M.C.V. Influence of the vertical grouting in the interface between corbel and beam in beam-to-column connections of precast concrete structures-an experimental analysis. Eng. Struct. 2018, 172, 201-213. [CrossRef]

13. Vasumithran, M.; Anand, K.B.; Sathyan, D. Effects of fillers on the properties of cement grouts. Constr. Build. Mater. 2020, 246, 118346. [CrossRef]

14. Wang, Z.; Zhu, J.; Wang, J.; Zhao, G.; Sun, S.; Zhang, J. Experimental study on a novel UHPC grout-filled pipe sleeve with mechanical interlocking for large-diameter deformed bars. Eng. Struct. 2021, 226, 111358. [CrossRef]

15. He, S.; Mosallam, A.S.; Fang, Z.; Zou, C.; Feng, W.; Su, J. Experimental study on CFSC encased shear connectors in steel-concrete composite joints with UHPC grout. Constr. Build. Mater. 2018, 173, 638-649. [CrossRef]

16. Tan, H.; Guo, Y.; Zou, F.; Jian, S.; Ma, B.; Zhi, Z. Effect of borax on rheology of calcium sulphoaluminate cement paste in the presence of polycarboxylate superplasticizer. Constr. Build. Mater. 2017, 139, 277-285. [CrossRef]

17. Belhadi, R.; Govin, A.; Grosseau, P. Influence of polycarboxylate superplasticizer, citric acid and their combination on the hydration and workability of calcium sulfoaluminate cement. Cem. Concr. Res. 2021, 147, 106513. [CrossRef]

18. Zhang, K.; Pan, L.; Li, J.; Lin, C. What is the mechanism of the fiber effect on the rheological behavior of cement paste with polycarboxylate superplasticizer? Constr. Build. Mater. 2021, 281, 12542. [CrossRef]

19. Soliman, N.A.; Tagnit-Hamou, A. Development of ultra-high-performance concrete using glass powder-Towards ecofriendly concrete. Constr. Build. Mater. 2016, 125, 600-612. [CrossRef]

20. Wang, X.; Yu, R.; Shui, Z.; Zhao, Z.; Song, Q.; Yang, B.; Fan, D. Development of a novel cleaner construction product: Ultra-high performance concrete incorporating lead-zinc tailings. J. Clean. Prod. 2018, 196, 172-182. [CrossRef]

21. Huang, W.; Kazemi-Kamyab, H.; Sun, W.; Scrivener, K. Effect of replacement of silica fume with calcined clay on the hydration and microstructural development of eco-UHPFRC. Mater. Des. 2017, 121, 36-46. [CrossRef]

22. Lee, C.L.; Huang, R.; Lin, W.T.; Weng, T.L. Establishment of the durability indices for cement-based composite containing supplementary cementitious materials. Mater. Des. 2012, 37, 28-39. [CrossRef]

23. Komabayashi, T.; Spångberg, L.S. Comparative analysis of the particle size and shape of commercially available mineral trioxide aggregates and Portland cement: A study with a flow particle image analyzer. J. Endod. 2008, 34, 94-98. [CrossRef] [PubMed]

24. Mehta, A.; Ashish, D.K. Silica fume and waste glass in cement concrete production: A review. J. Build. Eng. 2020, 29, 100888. [CrossRef]

25. Siddique, R. Utilization of silica fume in concrete: Review of hardened properties. Resour. Conserv. Recycl. 2011, 55, 923-932. [CrossRef]

26. Lin, W.T. Reactive ultra-fine fly ash as an additive for cement-based materials. Mater. Today Commun. 2020, 25, 101466. [CrossRef]

27. Chen, K.; Lin, W.T.; Liu, W. Effect of $\mathrm{NaOH}$ concentration on properties and microstructure of a novel reactive ultra-fine fly ash geopolymer. Adv. Powder Technol. 2021, 32, 2929-2939. [CrossRef]

28. Lin, W.T.; Lin, K.L.; Korniejenko, K.; Fiala, L. Comparative analysis between fly ash geopolymer and reactive ultra-fine fly ash geopolymer. Int. J. Eng. Technol. Innov. 2021, 11, 161-170. [CrossRef]

29. Shin, H.O.; Yoo, D.Y.; Lee, J.H. Development of $300 \mathrm{MPa}$ ultra-high-strength mortar through a special curing regime. Constr. Build. Mater. 2018, 20, 312-320. [CrossRef]

30. Meng, W.; Khayat, K.H. Improving flexural performance of ultra-high-performance concrete by rheology control of suspending mortar. Compos. B Eng. 2017, 117, 26-34. [CrossRef]

31. Liu, X.; Wang, Z.; Zheng, Y.; Cui, S.; Lan, M.; Li, H.; Zhu, J.; Liang, X. Preparation, Characterization and performances of powdered polycarboxylate superplasticizer with bulk polymerization. Materials 2014, 29, 6169-6183.

32. Chen, H.J.; Yu, Y.L.; Tang, C.W. Mechanical properties of ultra-high performance concrete before and after exposure to high temperatures. Materials 2020, 7, 770. [CrossRef]

33. John, S.K.; Nadir, Y.; Girija, K. Effect of source materials, additives on the mechanical properties and durability of fly ash and fly ash-slag geopolymer mortar: A review. Constr. Build. Mater. 2021, 280, 122443. [CrossRef]

34. Alsalman, A.; Dang, C.N.; Hale, W.M. Development of ultra-high-performance concrete with locally available materials. Constr. Build. Mater. 2017, 133, 135-145. [CrossRef] 
35. Larsen, I.L.; Thorstensen, R.T. The influence of steel fibres on compressive and tensile strength of ultra-high-performance concrete: A review. Constr. Build. Mater. 2020, 256, 119459. [CrossRef]

36. Liang, X.; Wu, C.; Su, Y.; Chen, Z.; Li, Z. Development of ultra-high-performance concrete with high fire resistance. Constr. Build. Mater. 2018, 179, 400-412. [CrossRef]

37. Arora, A.; Yao, Y.; Mobasher, B.; Neithalath, N. Fundamental insights into the compressive and flexural response of binder-and aggregate-optimized ultra-high-performance concrete (UHPC). Cem. Concr. Compos. 2019, 98, 1-13. [CrossRef]

38. Pyo, S.; Abate, S.Y.; Kim, H. Abrasion resistance of ultra high performance concrete incorporating coarser aggregate. Constr. Build. Mater. 2018, 165, 11-16. [CrossRef]

39. Hasnat, A.; Ghafoori, N. Abrasion resistance of ultra-high-performance concrete for railway sleepers. Urban Rail Transit 2021, 7, 101-116. [CrossRef]

40. Lin, W.T.; Wu, Y.C.; Cheng, A.; Chao, S.J.; Hsu, H.M. Engineering properties and correlation analysis of fiber cementitious materials. Materials 2014, 7, 7423-7435. [CrossRef]

41. Glasser, F.P.; Zhang, L. High-performance cement matrices based on calcium sulfoaluminate-belite compositions. Cem. Concr. Res. 2001, 21, 1881-1886. [CrossRef]

42. Sharp, J.P.; Lawrence, C.D.; Yang, R. Calcium sulfoaluminate cements-Low-energy cements, special cements or what? Adv. Cem. Res. 1999, 11, 3-13. [CrossRef]

43. Aranda, M.A.G.; de La Torre, A.G. Sulfoaluminate cement. In Eco-Efficient Concrete; Pachego-Torgal, F., Jalali, S., Labrincha, J., John, V.M., Eds.; Woodhead Publishing: Cambridge, UK, 2013; p. 488.

44. Kurdowsky, W.; Thiel, A. On the role of free calcium oxide in expansive cements. Cem. Concr. Res. 1981, 11, 29-40. [CrossRef]

45. Gastaldi, D.; Paul, G.; Marchese, L.; Irico, S.; Boccaleri, E.; Mutke, S.; Buzzi, L.; Canonico, F. Hydration products in sulfoaluminate cements: Evaluation of amorphous phases by XRD/solid-state NMR. Cem. Concr. Res. 2016, 90, 162-173. [CrossRef]

46. Wang, X.; Hou, P.; Yu, J.; Zhou, X.; Cheng, X. The effects of silica fume on $\mathrm{C}_{3}$ A hydration. Constr. Build. Mater. 2020, 250, 118766. [CrossRef]

47. Sakai, E.; Miyahara, S.; Ohsawa, S.; Lee, S.H.; Daimon, M. Hydration of fly ash cement. Cem. Concr. Res. 2005, 35, 1135-1140. [CrossRef]

48. Moghaddam, F.; Sirivivatnanon, V.; Vessalas, K. The effect of fly ash fineness on heat of hydration, microstructure, flow and compressive strength of blended cement pastes. Case Stud. Constr. Mater. 2019, 10, e00218. [CrossRef]

49. Xie, T.; Fang, C.; Mohamad Ali, M.S.; Visintin, P. Characterizations of autogenous and drying shrinkage of ultra-high performance concrete (UHPC): An experimental study. Cem. Concr. Compos. 2018, 91, 156-173. [CrossRef]

50. Soliman, A.; Nehdi, M. Effect of partially hydrated cementitious materials and superabsorbent polymer on early-age shrinkage of UHPC. Constr. Build. Mater. 2013, 41, 270-275. [CrossRef]

51. Collepardi, M.; Borsoi, A.; Collepardi, S.; Olagot, J.J.O.; Troli, R. Effects of shrinkage reducing admixture in shrinkage compensating concrete under non-wet curing conditions. Cem. Concr. Compos. 2005, 27, 704-708. [CrossRef]

52. Anshuang, S.; Ling, Q.; Shoujie, Z.; Jiayang, Z.; Zhaoyu, L. Effects of shrinkage reducing agent and expansive admixture on the volume deformation of ultrahigh performance concrete. Adv. Mater. Sci. Eng. 2017, 2017, 6384859. [CrossRef]

53. ASTM C 1202-19. Standard Test Method for Electrical Indication of Concrete's Ability to Resist Chloride Ion Penetration; ASTM International: West Conshohocken, PA, USA, 2019.

54. Mosavinejad, S.H.G.; Langaroudi, M.A.M.; Barandoust, J.; Ghanizadeh, A. Electrical and microstructural analysis of UHPC containing short PVA fibers. Constr. Build. Mater. 2020, 235, 117448. [CrossRef]

55. Mohd Faizal, M.J.; Hamidah, M.S.; Muhd Norhasri, M.S.; Noorli, I.; Mohamad Ezad Hafez, M.P. Chloride Permeability of Nanoclayed Ultra-High Performance Concrete; Hassan, R., Yusoff, M., Alisibramulisi, A., Mohd Amin, N., Ismail, Z., Eds.; Springer: Singapore, 2015.

56. Tai, Y.S.; El-Tawil, S.; ASCE, F.; Meng, B.; Hansen, W. Parameters influencing fluidity of UHPC and their effect on mechanical and durability properties. J. Mater. Civ. Eng. 2020, 32, 04020298. [CrossRef]

57. Teng, S.; Afroughsabet, V.; Ostertag, C.P. Flexural behavior and durability properties of high performance hybrid-fiber-reinforced concrete. Constr. Build. Mater. 2018, 182, 504-515. [CrossRef]

58. Vincler, J.P.; Sanchez, T.; Turgeon, V.; Conciatori, D.; Sorelli, L. A modified accelerated chloride migration tests for UHPC and UHPFRC with PVA and steel fibers. Cem. Concr. Res. 2019, 117, 38-44. [CrossRef]

59. Madani, H.; Norouzifar, M.N.; Rostami, J. The synergistic effect of pumice and silica fume on the durability and mechanical characteristics of eco-friendly concrete. Constr. Build. Mater. 2018, 174, 356-368. [CrossRef]

60. Li, P.P.; Brouwers, H.J.H.; Chen, W.; Yu, Q. Optimization and characterization of high-volume limestone powder in sustainable ultra-high performance concrete. Constr. Build. Mater. 2020, 242, 118112. [CrossRef]

61. Huang, W.; Kazemi-Kamyab, H.; Sun, W.; Scrivener, K. Effect of cement substitution by limestone on the hydration and microstructural development of ultra-high performance concrete (UHPC). Cem. Concr. Compos. 2017, 77, 86-101. [CrossRef]

62. Ren, M.; Wen, X.; Gao, X.; Liu, Y. Thermal and mechanical properties of ultra-high performance concrete incorporated with microencapsulated phase change material. Constr. Build. Mater. 2021, 273, 121714. [CrossRef]

63. Yujing, L.; Wenhua, Z.; Fan, W.; Peipei, W.; Weizhao, Z.; Fenghao, Y. Static mechanical properties and mechanism of C200 ultra-high performance concrete (UHPC) containing coarse aggregates. Sci. Eng. Compos. Mater. 2020, 27, 186-195. [CrossRef]

64. Jing, R.; Liu, Y.; Yan, P. Uncovering the effect of fly ash cenospheres on the macroscopic properties and microstructure of ultra high-performance concrete (UHPC). Constr. Build. Mater. 2021, 286, 122977. [CrossRef] 